\title{
Disrupted vs. sustained humor in colloquial conversations in peninsular Spanish
}

\author{
Leonor Ruiz-Gurillo \\ University of Alicante, GRIALE Research Group, Spain
}

\section{A R T I C L E I N F O}

\section{Article history:}

Received 19 October 2020

Received in revised form 17 March 2021

Accepted 18 March 2021

\section{Keywords:}

Conversational humor

Colloquial conversation

Irony

Humorous sequence

Humor

\begin{abstract}
A B S T R A C T
This paper shows the results of an analysis of humor in conversations in Peninsular Spanish, balanced between the short disruption of the progress of conversation and the sustained humor along a sequence. 67 conversations of a total duration of approximately 945 min were compiled, and from these conversations 148 humorous sequences were extracted. The data shows a trend (40\%) towards the Least Disruption Principle (Eisterhold et al., 2006; Attardo et al. 2011, 2013), since irony and humor occur in a single turn and responses are limited to a later turn in $14 \%$ of instances. However, our corpus supports a wide-ranging trend towards sustained humor (Attardo, 2019) over more than three turns (46\%). Additionally, the type of response (Kotthoff, 2003) is analyzed: to the said (11.36\%), to the implied (19.32\%), laughter (13.64\%) and mixed responses (55.68\%). Our analysis of humorous sequences indicates that there is a consistent framework in which as mixed responses increase, the humorous mode is fostered in colloquial conversations.
\end{abstract}

(C) 2021 Elsevier B.V. All rights reserved.

\section{Introduction}

The aim of this research work is to challenge both the Least Disruption Principle (Eisterhold et al., 2006) and the sustained humor (Attardo, 2019, 2020) in a corpus of 67 colloquial conversations of Peninsular Spanish. Although studies in conversational humor have mainly focused on English, this paper intends to provide a better understanding of how humor works in interaction in languages other than English (Schnurr and Plester, 2017: 318), namely in spontaneous face-to-face conversations.

Research describes irony and humor as a strategy which participants use in a number of limited turns. In order to respect the Gricean Cooperative Principle and, specifically, the Least Disruption Principle (LDP) (Eisterhold et al., 2006; Attardo et al., 2011; Attardo et al., 2013), speakers bend these rules, if necessary, in the direction the audience expects, although they minimize this distance. Salvatore Attardo and his team argue that the LDP works with the different corpora used for English, as well as that submitted by Tsakona (2011) for Greek and Ruiz-Gurillo (2009) for Spanish. Concretely, Attardo et al. (2013: 413 ) state that $48.5 \%$ of ironic exchanges are made up of a single turn, while $68.5 \%$ of the remaining exchanges consist in 3 or less turns. As a result, the LDP has proved to be an efficient tool since ironic turns are frequently followed by smiling and/or laughter, although these ironic-humorous exchanges do not usually extend over more than three turns. 
It is worth noting that the corpus studied by Attardo and his team is made up of dyadic conversations and interactions, specifically recorded to show irony and humor. ${ }^{1}$ Our research is underpinned by a corpus of 67 real colloquial conversations in Spanish from the Val.Es.Co. research group (www.valesco.es). The Val.Es.Co. corpus was recorded with a system that recognized typical patterns in colloquial conversations (Briz and group Val.Es.Co., 1995 and 2002) and transcribed with a specific system which was inspired by the Jeffersonian method (Sacks et al., 1974). The database is composed of real conversations that document spontaneous and oral discourse, in such a way that a high number of phenomena may be analyzed, for instance, discourse markers, mitigation, word order, irony, humor, etc. ${ }^{2}$

Considering these facts, the following study hypotheses have been drawn up:

1. Humor in colloquial conversation seeks to find a balance between a minimum interruption of the sequence, that is, the preeminence of LDP, and a sustained humor among the sequence.

2. Colloquial conversation is conducive to humor sequences where sustained humor takes precedence over LDP. In these interactions there is social equality among participants who share experience, interact in a non-marked interactional framework such as the home or the street and develop non-specialized topics.

This paper has been organized as follows: Section 2 includes the review of the literature on conversational humor, mainly focused on antagonist concepts of the Least Disruption Principle (Eisterhold et al., 2006) and sustained humor (Attardo, 2019, 2020). Reactions to irony and humor in interaction are also described, following Kotthoff (2003). The unit of analysis will be the humorous sequence, which is explained accordingly, as well as the concept of irony in conversations. Section 3 presents the methodology used for the study on humorous sequences in colloquial conversations in Peninsular Spanish. Section 4 shows different types of reactions to humor in the VALESCO.HUMOR corpus, followed a quantitative analysis (Section 5). Finally, in the conclusions section, the main ideas will be summarized and the hypotheses will be corroborated.

\section{Conversational humor}

\subsection{Reactions to conversational humor}

This paper belongs to the line of conversational humor based on Ethnography of Communication by J. Gumperz and D. Hymes (1986) and Interactional Sociolinguistics by E. Goffman (1981). In fact, it offers an attempt to understand how speakers use humor and irony to convey a complex social meaning when interacting (Davies, 2017: 483). The term has been defined by Coates (2007: 29) as "humorous talk occurring in the informal conversation of friends". Moreover, research is focused on how humor works in discourse (Coates, 2014) and how social variables interact with it (age, gender, ethnic group, etc.) (Hay, 2000: 717), not only in informal conversations, but also in business environments (Coates, 2007; Holmes et al., 2001). Thanks to the research on conversational humor (Norrick and Chiaro, 2009; Dynel and Sinkeviciute, 2017; Mullan and Béal, 2018; Sinkeviciute, 2019; Mullan, Vincent-Durroux and David, 2020), certain preconceptions about the use of irony and humor in interaction can be refuted, such as negativity towards the listener and the lack of humor in turns from women. In contrast, research based on corpora corroborate their use as cohesive devices, i.e. for maintaining solidarity in situations of social equality (Anolli et al., 2001; Gibbs and Colston, 2001; Norrick, 2003; Giora and Gur, 2003); as differentiating factors in terms of gender (Lampert and Ervin-Tripp, 1998, 2006, 2006; Davies, 2003, 2006; Norrick and Spitz, 2008, 2010); and even in an intercultural and contrastive context (Dynel and Sinkeviciute, 2017; Mullan and Béal, 2018; Haugh and Weinglass, 2018; Priego-Valverde, Bigi, Attardo, Pickering and Gironzetti, 2018; Sinkeviciute and Dynel, 2019; Mullan et al., 2020). ${ }^{3}$

Focused on irony and humor in spontaneous conversation, a line of research is devoted to the type of response provided by the listener (Eisterhold et al., 2006; Attardo et al. 2011, 2013; Attardo 2019, 2020). Concretely, Eisterhold et al. (2006) suggest irony entails the infringement of the Principle of Cooperation, so listeners minimize this violation by frequently limiting the ironic utterance to a single turn. By way of explanation, they put forward the Least Disruption Principle (LDP) which is integrated into the Non-Cooperative Principle (NCP) set out by Attardo (1997) and (1999), which is based on the following super-maxim:

Minimize your violation of the Cooperative Principle (CP)

This principle has been completed with the following maxims (Eisterhold et al., 2006: 1243):

\footnotetext{
1 Eisterhold et al. (2006: 1246) use a corpus made up of 395 ironic or sarcastic utterances collected immediately after they were made, following the principle of non-participating observer or participating observer. These excerpts have been recorded in the form of help notes after observation. The samples are face-to-face interactions, classes and exchanges in customer service. The pilot study of Attardo et al. (2011) is based on 1 dyadic conversation. This corpus was extended by Attardo et al. (2013: 403), who used 4 dyadic conversations in which the speakers were told how to tell a joke to their listeners and then they had to chat freely for $5 \mathrm{~min}$. This brought 39 humor utterances to the corpus.

2 You can visit the webpage http://www.valesco.es/web/biblio.html?cmd=reset for accurate information about research on colloquial conversations.

${ }^{3}$ A comprehensive literature review on the sociolinguistic analysis of humor can be found in Davies (2017). In the review, the author includes some of the works commented on herein.
} 
1. Limit your violation of the $\mathrm{CP}$ to the smallest possible conversational unit (one utterance, one conversational turn, one speech exchange).

2. Try to link the entire $\mathrm{CP}$-violating unit to the rest of the interaction, for example, by finding a certain appropriateness to the CP-violating unit.

3. Limit your violation of $\mathrm{CP}$ to the smallest possible distance from its requirements.

4. If you must violate a maxim, do so in the direction that is expected by your audience (i.e. say what your audience wants to hear).

As stated by the authors, the maxims are not all equally used in irony, with 3 and 4 being the most important ones. This implies that in interactions with irony, it is restricted to a single turn, or failing that, it does not go beyond 2 or 3 turns.

In this way the LDP becomes a general principle that is assumed in exchanges in which there is irony. In some works, such as Ruiz-Gurillo (2009, 2012) and Tsakona (2011), this principle has been criticized and data is provided to refute it. However, and despite such criticism, Attardo et al. (2013: 413) suggest their LDP still works as a general principle and both works support this. As for the second piece of research "[...] Ruiz-Gurillo (2009) found that 48.5\% of her corpus of ironical exchanges consisted of single turns and $68.5 \%$ consisted of three or less turns".

More recent research studies (Attardo, 2019, 2020), despite keeping the LDP as a framework, suggest that occasionally there is sustained humor. This is defined as "conversational sections which are keyed (or framed) for humor and last more than 3 turns" (Attardo, 2019: 190). In sustained humor just a few of the phenomena observed are:

- Different speakers use co-constructed humor.

- Mode adoption is maintained, so that, for example, irony is responded to with irony.

- There is humor support (Hay, 2001), since the interlocutor validates the humor of the speaker.

- Long turns are dominated by the speaker. The listener responds to these with backchannels, which guide the conversation towards humor. ${ }^{4}$

Some of these aspects have already been mentioned in research on conversational humor, such as that by Hay (2001), Priego-Valverde (2003) and Kotthoff (2011) concerning humor support, and such as the research by Raskin (1985), Attardo (1997) and Shilikhina (2017), regarding mode adoption and non-bona fide communication.

It is well-known that conversational humor studies have focused mainly on English and his terminology (Goddard, 2020). By contrast, approaches in other languages are scarce. Notable exceptions are provided by Béatrice PriegoValverde and Helga Kotthoff. For instance, Priego-Valverde (2003) and (2006) analyzed spontaneous conversation in French by means of a corpus of 9 recorded interactions as well as other textual examples. These ones occurred between friends or among family members and have created long-lasting interactions. One of the most notable functions found in her corpus is the use of humor as a ludic co-construction (Priego-Valverde, 2003: 177) in which different participants construct the sequence. Therefore, according to the author, humor in conversation has a wide range of functions such as encouraging cooperation and competition, playing with ambivalence and providing a means to escape or play.

Moreover, the range of works by Helga Kotthoff (2000), (2003), (2006a), (2006b) and (2011) make an in-depth exploration of irony and humor in German. In Kotthoff (2003) there is a focus on humor in interaction, and 51 ironic sequences belonging to $30 \mathrm{~h}$ of dinner and private conversations are compared to 24 ironical sequences from $20 \mathrm{~h}$ of television debates. She differentiated responses to the said, the implied, mixed responses, ambiguous responses and responses with laughter. So, in the corpus of informal conversations, the most typical response was to the said (50.9\%), while in the debates the main one was to the implied (58.3\%). Table 1 shows the results on dinner conversations.

Table 1

Reactions to irony in dinner conversations (Kotthoff, 2003: 1407).

\begin{tabular}{llllll}
\hline To the said & To the implied & Laughter & Mixed reactions & Ambiguous reactions \\
\hline $50.9 \%$ & $7.8 \%$ & $11.8 \%$ & $19.6 \%$ & $9.8 \%$ & $100 \%$ \\
\hline
\end{tabular}

As for Spanish, there are also scant approaches, although there is some outstanding research from GRIALE research group, specially papers by Alvarado (2013), (2014), (2016a) and (2016b) on failed humor in Spanish conversations which stems from the ideas of Bell (2009). The author establishes instances in which humorous turns are recognized, understood and noted, but not responded to or, conversely, are accepted and these ones constitute a response. Specifically, Alvarado (2016a) analyzed 30 occurrences in colloquial conversations between women and 30 between men, taken from the Val.Es.Co. corpus 2.0 (http://

\footnotetext{
4 According to Attardo (2019: 206), sustained humor is the result of a feedback loop. Its most notable features include facial expression, influence of mirror neurons on listeners, reactions, etc.
} 
www.valesco.es/?q=consulta). In order to strengthen the bonds of the conversational group, women sustain humor, or, alternatively, do not recognize or respond to it, and consequently humor fails. However, men use both sustained humor and failed humor to protect their public image from attacks from the listener (Alvarado, 2016a: 212).

\subsection{The concept of a humorous sequence}

Actions within informal conversations are organized into sequences (Schegloff, 2007). All in all, a humorous sequence is a type of interaction when humor works. Priego-Valverde (2003), (2006) and Priego-Valverde et al. (2018) draw on it to fulfill a range of functions of humor, such as confirming opening and closing sequences, managing turns to speak, defusing conflicts, etc. Norrick and Spitz (2008) use it to explain the role humor plays, mainly in mitigating conflict. Incorporated into the humor parameters, Glenn and Holt (2017: 296) give it an intrinsic value, as they try to separate the truly humorous sequences, in which jokes are told and pranks are played, from those that are not. ${ }^{5}$

This general system for segmentation has been taken into account when dividing the ironic and humorous exchanges in our corpus of colloquial conversations, called VALESCO.HUMOR. A humorous sequence is understood as a conversational structure that is composed of several turn-taking on the same topic. In these instances, irony and humor are used as discursive strategies. Speakers frequently tone down the serious mode of the conversation with an ironic turn. A turn is a structural unit by a participant. Basically irony is based on implying the opposite of what the words say, i.e., speakers commonly use a prototypical irony (Ruiz-Gurillo and Padilla-García, eds. 2009). This ironic turn may or may not be sustained by the other participants. The more turns the response occupies, the easier it will be to find a sustained humor sequence (Attardo, 2019). When the humor is sustained, an ironic-humorous sequence is created in which there is a marked humorous mode. Thus, the humorous mode is one of the non-bona fide types of communication (Raskin, 1985; Attardo and Raskin, 1991; Partington, 2006; Shilikhina, 2017). While bona fide communication is cooperative, non-bona fide is not. So, firstly, the speaker is not committed to telling the truth and, secondly, the listener is aware that there is no such commitment (Raskin, 2007: 99). Although, obviously, there is no dichotomic distinction between cooperative and non-cooperative communication (Shilikhina, 2017: 117), since humor, irony and sarcasm, lies/hypocrisy and absurd communication constitute four types of non-bona fide communication that are situated in the fuzzy zone in which the cooperation principle is but not strictly defined either. $^{6}$

Consequently, a humorous sequence is a unit of segmentation in which humor and irony occur. In our opinion, irony and humor frequently work jointly in this unplanned register and, in such a way, an ironic turn might be the germ of the humorous mode. Thus, irony may disrupt the conversation along one or two turns. However, when the speaker adopts a humorous mode, humor might be sustained among a sequence. Thus, the speaker may warn the listener using some humor markers and indicators (Ruiz-Gurillo, 2016). For the GRIALE research group (http://griale.dfelg.ua.es/), a humor marker is a linguistic, paralinguistic or extralinguistic element which helps to infer humor. Some of the markers that appear in informal conversations are intonation, pauses, gestures, discourse markers, evidentials, etc. Concretely intonation is one of the main markers. However, it plays together with pauses and some gestures which the transcriber points in some footnotes. Likewise, an indicator is an element that could turn into a humorous cue in a specific context. In texts in which there is informal, oral speech, i.e. spontaneous conversation, indicators such as polysemy, phraseology, hyperboles and quantifiers, etc. are frequently used. For instance, speaker uses a hyperbole, a wordplay or an idiom in a humorous way. ${ }^{7}$

\section{Methodology}

A quantitative and qualitative methodology was used in this work. A total of 67 colloquial conversations from the Val.Es.Co. corpus, lasting approximately 945 min were selected. The Val.Es.Co. corpus includes authentic colloquial conversations which have been registered following an established recognition system (Briz and the Val.Es.Co. group, 2002). This system is based on four colloquial features, i.e. the social equality and a shared experience among participants, a non-marked interactional framework in which the communication goes forward, and a non-specialized topic. The social variables of age, sex, educational level were also taken into account. With these criterion, a corpus of colloquial conversations in Peninsular Spanish was built up between 1990 and 2012 in Valencia, Spain. Due to their authenticity, the corpus contains informal conversations between 2, 3, 4 and more participants with a variable duration between 10 and 50 min.

\footnotetext{
5 Attardo (2001: 83) prefers the term strand to segment humorous discourse, although he has been inspired by textual analysis and isotopies.

${ }^{6}$ Humor as non-bona fide communication is defined by the following features (Shilikhina, 2017: 117).

- An additional cognitive effort is required so as to interpret the utterance as being humorous.

- The humorous discourse means the scenario is playful. Therefore, the speaker wishes his or her listener to interpret the utterance within a playful framework.

- The degree of cooperation is heightened, although the speaker remains rational and cooperative. This shows that, despite everything, humor is still a cooperative process which does require more inferential work.

- If necessary, the humorous intention is explicitly shown by means of expressions such as I'm just kidding and it's a joke.
}

7 For a comprehensive study of humor markers, see Burgers and Mulken (2017). 
The selected conversations ${ }^{8}$ for this study were divided into humorous sequences, using the sequence concept described above. Extralinguistic information provided in the transcriptions was also used, such as the notes LAUGHTER, LAUGHTERTALK, and specific information contained in the footnotes. Likewise, given that paralinguistic aspects such as laughter do not constitue humor in themselves, ${ }^{9}$ when selecting the sequences, a system of markers, such as intonation, pauses, gestures, etc., and an analysis of indicators, such as the use of polysemic expressions, hyperboles and quantifiers were used for labelling the sequences (Ruiz-Gurillo, 2012, 2014).

Another criterion used was to identify whether the irony just occurred in a single turn or whether it was responded to by one of the listeners, by several of them, or throughout different turns. If the listener responded, it was determined whether this was to the said, to the implied, only with laughter or with a mixed response ${ }^{10}$ (following Kotthoff, 2003). At the same time, there was an assessment not only of whether the ironic-humorous turn was sustained but also of how many turns there were. If irony is restricted to a single and monological turn, the code M1 is used. If irony and humor is responded to a dialogical turn-taking, codes D2, D3, D4, D5, D6, D7 and D8 are used to express the duration of the responses along the sequence. Dn has been used to indicate that irony and humor is extended beyond 8 dialogical turns.

Out of the 43 conversations with irony and humor, 148 humorous sequences lasting 70 min in total have been extracted. These humorous sequences make up part of the VALESCO.HUMOR corpus which has been incorporated into www. observahumor.com. The sequences have been digitalized, compiled and uploaded onto the Internet. By running searches on the system, the sequence transcribed from the audio can be found, which is aligned with the full sequence by means of the ELAN program. Likewise, the online application allows searching through the variables: gender (male/female), age ( $<26$, $26-55,>55$ ) and educational level (high/average/low). In the near future this platform will facilitate other ways of research on irony and humor in Spanish conversation.

\section{Reactions to irony and humor in conversation}

The VALESCO.HUMOR corpus, composed of 148 humorous sequences, contains examples of humor and irony which are restricted to a single turn or a turn and a response with laughter and/or smiles. But, at other times, these turns are accepted by the listeners, which turns them into sustained humor sequences and encourages talk in environments where humorous mode takes precedence. Humor is therefore fostered along many turns. Irony in a single turn (4.1.), responses to the said (4.2.), to the implied (4.3.), with laughter (4.4.) and with mixed responses (4.5.) are illustrated below. Finally, when the humorous mode is supported, sequences with sustained humor are expected (4.6).

\subsection{Irony in a single turn}

Typically, in colloquial conversations in Peninsular Spanish one of the participants picks up on something the speaker has said without irony and answers using these words in an echoic use (Wilson, 2000). This explanation is also in keeping with the concept of irony developed by Ruiz-Gurillo and Padilla-García (eds.) (2009). This is what happens in (1). P asks their listeners what she is going to do at the weekend. In answer to the response of R, V picks up on her words ("MOPE AROUND") to respond ironically. Laughter, an ironic intonation and the intensity of voice of more around (transcribed as capital letters) are the markers of this turn. ${ }^{11}$

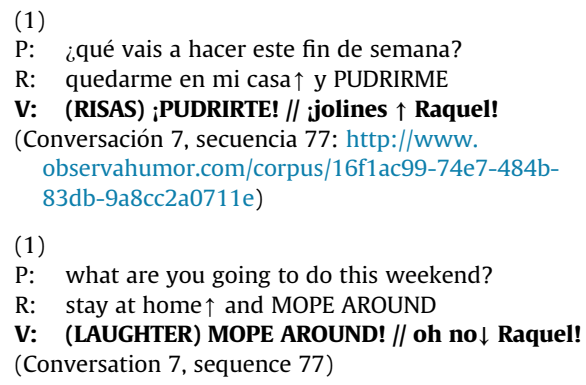

\footnotetext{
8 The conversations come from the Val.Es.Co. corpus. 2.0, accessible at www.valesco.es, from the 2002 Val.Es.Co. corpus. available at the Briz and the Val. Es.Co. group (2002) and other colloquial conversations collected by the research group and which are in the process of being digitalized.

${ }^{9}$ As Kotthoff stated (2000: 64), laughter is the ultimate indicator that humor is present, although it is not a sole exclusive indicator of humor. Due to the fact laughter is well-known not to indicate humor at all (Partington, 2006), other markers are considered for the selection of sequences, such as intonation, gestures, etc.

10 Both mixed and ambiguous responses were considered here as mixed responses, in contrast to the database of Kotthoff (2003).

11 The transcription keys used by Val.Es.Co. can be consulted on the website http://www.valesco.es/sistema.pdf, some of which have been reproduced here: short pause $-<0.5 \mathrm{~s}(/)$, average pause $[0.5,1] \mathrm{sec}(/ /)$, long pause $>1 \mathrm{~s}(/ / /)$, continuation of turn (=), overlaps [ ], falling intonation $(\downarrow)$, rising intonation $(\uparrow)$, suspended intonation $(\rightarrow)$, language uttered with lower intensity ${ }^{\circ}()^{\circ}$, language uttered with higher intensity (capital letters), no pause between turns $(\S)$, direct speech (italic letters).
} 


\subsection{Responses to the said}

Even though irony is usually localized in a single turn, responses that extend over different turns can also be found. Here irony is dialogical by nature, as it is sustained over a single and even various turns. The most representative example of this is a localized response in a turn which responds to the said, as occurs in (2), where the participants comment that they have not seen Adela for a while because she might have been in a sports event. C challenges this assumption and suggests that it may be an event "for morons anonymous", playing as an echo (Wilson, 2000) with the expression "Alcoholics Anonymous". In response, $\mathrm{A}$ answers to the said with the expression "karates anonymous". ${ }^{12}$

(2)

B: [¡oye!] no es por nada pero Adela $\uparrow$ eeh hace así como un mes $\uparrow / /$ que noo ha aparecido por el centro

C: ¿por qué?

B: $\quad$ [yo no la he visto=]

A: [compitee]

B: $\quad=$ yo no la he visto hacee mira $\downarrow$ dos reuniones o tres de sector $\downarrow$ que no lle- no ha venido/ Campobosco $\uparrow$ no ha venido $\downarrow$ [hoy $\uparrow$ no ha venidoo]

A:

B: $\quad$ [joder tíaa]

C: $\quad[(())] / /$ ¿concentración de qué $\uparrow$ de subnormales anónimos?

B:

A:

$\mathrm{B}: \quad$ = venir hoy tía y al final miraa// y no me apetecía nada venir hoy/ ara ya iguay! tía/ porque ijoder!

(Conversación 20, secuencia 79: http://www.observahumor.com/corpus/b49475ed-f8ab-48dc-9543-e884b2c40f8a)

(2)

B: [hey!] don't get me wrong but Adela // mm she hasn't shown up at the center for aboout a month

C: why?

B: $\quad$ [ I haven't seen her $=$ ]

A: [she competees]

B: $\quad=$ I haven't seen her for- well look $\downarrow$ two or three meetings $\downarrow$ she hasn't sho- / she hasn't come to $\uparrow$ Campobosco $\downarrow$ [today $\uparrow$ she hasn't come]

A:

B: $\quad[$ damm $\downarrow$ girl! ]

C: $[(())] / /$ an event for what? morons anonymous?§

B: $\quad \S[$ I don't feel like $=$ ]

A: $\quad \S$ [yes/ karates anonymous]

B: = coming today either/ but anyway look// I didn't feel like coming today at all/ but hey $\downarrow$ don't worry! / damm $\downarrow$ girl!

(Conversation 20, sequence 79 )

Thus, although A comments that Adela might have been training for a sports event and that is why they have not seen her for a while, $C$ picks up on this to create an ironic turn and, afterwards A responds to the said in a humorous mode.

\subsection{Responses to the implied}

According to our data, the longer the response is extended, the more likely they are to be to the implied and not to the said. In fact, this circumstance often creates sustained humor that encourages a humorous mode to be adopted in the conversation. This is shown in example (3). The participants talk about taking notes on what the others say in any conversation, emulating students in a class.

(3)

J: buenoo ¿luego vais a copiar lo que yo voy a decir?§

C:

$\mathrm{N}$ : generosa

$\mathrm{J}:$ a la hora de analizar el espacio/ [aparte]

C. $\mathrm{N}$ :

[a la hora] [(RISAS)]

[(RISAS)] más despacio por favor (RISAS) eso es como cuando- cuando vas a la facultad $\mathrm{y} \rightarrow$ no os habéis dado cuenta que- que entras y dice el profesor ;hola! ¡buenos días! y se ponen a copiar/ y prácticamente tú ¿qué coño estarán copiando $\downarrow$ hola buenos días? porque vamos $\rightarrow$

(Conversación 22, secuencia 81: http://www.observahumor.com/corpus/88853ca1-678c-412a-84d1-d9cab718c375)

(3)

$\mathrm{J}$ : well then are you going to take notes on what I am going to say?

C:

$\mathrm{N}$ : generous

J: when analyzing space/ [apart]

C: [when analyzing] [(LAUGHTER)]

$\mathrm{N}: \quad \quad$ [(LAUGHTER)] slowly please (LAUGHTER) this is like when- when you go to college and $\rightarrow$ haven't you noticed that- you enter and the teacher says hi! good morning! and they start copying/ and you think what the hell are they copying $\downarrow$ hi $\downarrow$ good morning? I mean come off it $\rightarrow$

(Conversation 22, sequence 81)

\footnotetext{
$\overline{12}$ Examples may be listened at the website www.observahumor.com. Thanks to the audio of the sequences, the ironic intonation used by the participants can be observed.
} 
In answer to the ironic response of C ("of course, I'm going to take notes"), $\mathrm{N}$ responds to the implied with another equally ironic response ("generous"). ${ }^{13}$ Then, he uses this hyperbole with a specific intonation. The rest of the participants support the humor (Hay, 2001) and sustain the humorous mode. The fact that a funny and playful situation is being talked about and that the butt of the joke is a teacher helps the humor in this sequence to strengthen bonds among the students.

\subsection{Responses with laughter}

In the corpus of conversational sequences laughter is the sole response in just few instances, thereby partly contradicting the intuitive concept that laughter is one of the most frequent responses. In (4) it is P who brings up a serious topic, the Gulf War, but she calls it "Star Wars". So, C reacts with laughter which overlaps with the turn of her interlocutor. Afterwards, P also reacts with laughter picking up on her own words.

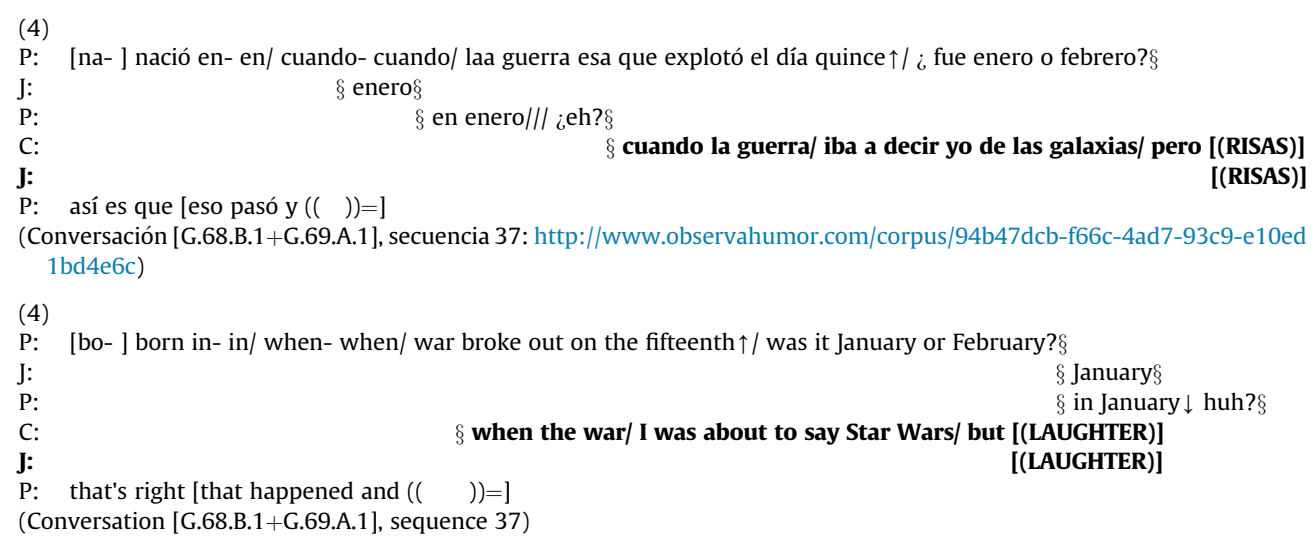

\subsection{Mixed responses}

On the contrary, mixed responses are the most plentiful in VALESCO.HUMOR corpus and the most frequent when there is irony and humor in 6, 7 or more turns (D6-Dn; see Methodology). These instances show that when humor is sustained, a humorous sequence in which most responses are to the implied is created and this is combined with laughter. This can be seen in (5), where irony and humor are extended over 6 turns and are combined with responses to the implied and to laughter. The participants tell a story related to an egg in a typically humorous sequence.

(5)

C: tendrías que habernos visto en selectividad a NOSOTRAS

A: en selectividad a las tres de la mañana $\uparrow / /$ aquí la menda y la otra menda que ahora no está [se comieron=]

C: [(RISAS)]

A: $=$ un huevo $\downarrow$ a las tres de la mañana un huevo HERVIDO $\$$

C: $\quad \$$ un huevo duro [(RISAS)]

A: $\quad$ [mira] pero es que cuando veas el vídeo $\uparrow$ te lo juro que te vas a reír ieh?§

$\S$ en exámenes siempre podríamos traer algo porque $(())$ un agobio encima

$\S[(())]$

$\S[((\quad))]$ el huevo duro que- que está blando $\downarrow$ el huevo duro no estaba bastante duro y se nos caía

(Conversación [M.171.A.1], secuencia 125: http://www.observahumor.com/corpus/1631e6bb-f939-4d7a-99c2-079388252265)

(5)

C: You should have seen US when we were studying for the university entrance exams

A: studying for the university entrance exams at three a.m. $\uparrow / /$ here the guy ${ }^{14}$ and the other guy who is not here now [eating=]

C: $\quad$ [(LAUGHTER)]

A: $\quad=$ an egg $\downarrow$ at three a.m./ a BOILED egg $\S$

C:

A:

B

A:

C:

\section{$\S$ a hard-boiled egg [(LAUGHTER)]}

[look] but when you watch the video $\uparrow$ I swear you'll laugh eh?§

$\S$ in the exams we could always bring something because (( )) there's a further burden $\S$

egg- a soft-boiled one $\downarrow$ the egg wasn't boiled enough and we dropped it

(Conversation [M.171.A.1], sequence 125)

\footnotetext{
13 The cue is the ironic intonation used by C, as it may be listened at the website www.observahumor.com.

${ }^{14}$ A noise is heard.
} 
In (5) speakers A and C are the ones to co-construct the story of the boiled egg for B in an amusing way. The feedback between them means the humor is sustained over at least 6 turns. As a result, the sequence can only be interpreted in humorous mode.

\subsection{Supporting the humorous mode}

As the VALESCO.HUMOR corpus shows, when the responses are located over different turns, truly humorous sequences are found more frequently. Obviously, colloquial features, such as social equality among participants who share previous experiences, play in a non-marked interactional framework such as the home or the street and speak on non-specialized topics, are conducive to the appearance of such sequences. In this sense, humorous texts, such as jokes, can frequently be found in colloquial conversations. In these cases, the different participants collaborate in the story, whether this is by adding to the joke, or commenting on the interpretation or comprehension of the story, thereby helping to sustain the humor (Alvarado, 2013a, 2016a; Attardo, 2019, 2020). This is what happens in (6), where three women under 25 years old participate. In fact, the colloquial feature of social equality fosters the humorous mode. ${ }^{15}$ Moreover, the non-specialized topic of contraceptives is brought up, which - although in other situations may be deemed taboo - here supports the humor and hence develops the sequence. B begins speaking about a brand of condoms called Control. This prompts $C$ to tell a joke about condoms and the rest of the participants to sustain the humor created. C plays with the form of the word Control and she wonders whether he wants the condom "with or without troll", the archenemy of David the Gnome.

(6)

B: los Control

A: ¿los quée?

C: los preservativos Control

B: porque no te importaría ¿no?

C: ¡ay! ¿os sabéis el chiste este? ¿no?

A: ¿cuál?

C: ¿me da un preservativo $\uparrow$ Control?/// no sino- no no el que va ;ostras! va un gnomo a una farmacia§

B:

C: un gnomo $\downarrow$ síi un gnomo y el gnomo

$\S$ ¿un gnomo?

A: un gnomo de gnomo

B: un gnomo de gnomo $[($ RISAS $)=]$

A:

C:

B: $=(())$

C: ¿David el gnomo?

B: (( ))

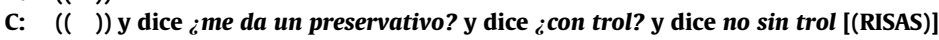

A:

[(RISAS)]

[(RISAS)]

B:

MUY malo

[(RISAS)]

[(RISAS)] eso es muy malo Elena ¿visteis el lunes Genio y figura? porque es

(Conversación [M.171.A.1], secuencia 129: http://www.observahumor.com/corpus/f8d06254-2bca-4751-ad05-1bca6313d266)

(6)

B: Control $^{16}$

A: what?

C: Control condoms

B: because you wouldn't mind $\downarrow$ would you?

C: oh! do you know this joke? you don't?

A: which one?

C: can you give me aa Control condom? // no $\downarrow$ no the one that goes like this ${ }^{17}$ a gnome goes to a drugs store $\S$

C a gnome yes $\downarrow$ a gnome ${ }^{18}$ and the gnome

A: a gnome $\downarrow$ you know $\downarrow$ a gnome ${ }^{19}$

B: a gnome $\downarrow$ a gnome! ${ }^{20}[($ LAUGHTER $)=]$

A: [(LAUGHTER)]

C: $\quad$ [(LAUGHTER)]

$\mathbf{B}=(())$

C: David the gnome ${ }^{21}$ ?

\footnotetext{
15 Although VALESCO.HUMOR contains most sequences in which there are three or more participants, example (6) forms part of a dyadic conversation. Further research might point out differences between dyadic and other sequences, as well as cultural aspects which help to foster humor.

16 Condoms brand.

17 Laughter-talk.

18 Laughter-talk.

19 Laughter-talk.

20 Laughter-talk.

21 David the Gnome is a cartoon character.

22 "Con" means in English "with", hence the pun on the Con-trol brand of condoms.

23 Television program in which various comedians participate telling jokes.
} 
B $\quad(())$

C: (( )) and says give me a condom? and they ask with ${ }^{22}$ trol? and he says no without a troll [(LAUGHTER)]

A:

[(LAUGHTER)]

B

[(LAUGHTER)] that's awful Elena $\downarrow$ did you see Genio y

figura $^{23}$ on Monday? because it's AWFUL

(Conversation [M.171.A.1], sequence 129)

Examples such as (6) specifically support the point that sustained laughter is linked to primary features, such as conversational dynamism between speaker and listener, lack of planning and feedback between speaker and listener. Moreover, the wide range of colloquial features, such as social equality, shared experiences and a non-specialized topic are also conducive to this. Consequently, the sequence is de-veloped in humorous mode that is sustained over different turns.

\section{Quantitative analysis}

It is stated that a high number of conversations from the Val.Es.Co. corpus contains humorous sequences. This is shown in Table 2 .

Table 2

Number of colloquial conversations and conversations with humorous sequences.

\begin{tabular}{lll}
\hline Corpus of colloquial conversations & Total & Percentage \\
\hline Number of conversations & 67 & $100 \%$ \\
Number of conversations with humorous sequences & 43 & $64.17 \%$ \\
\hline
\end{tabular}

Firstly, the corpus of 148 humorous sequences corroborates the point that a substantial part of the sequences (60) fulfill the LDP. In other words, humor is restricted to a single and monological turn (which is shown with the code M1). However, the corpus provides many results linked to sustained irony and humor over 2, 3, 4, 5, 6, 7, 8 or more dialogical turns of response. As explained above (see Methodology), the codes D2, D3, D4, D5, D6, D7 and D8 show the number of dialogical turns and, lastly, Dn has been used to indicate that irony and humor is extended beyond 8 dialogical turns, as shown in Fig. 1.

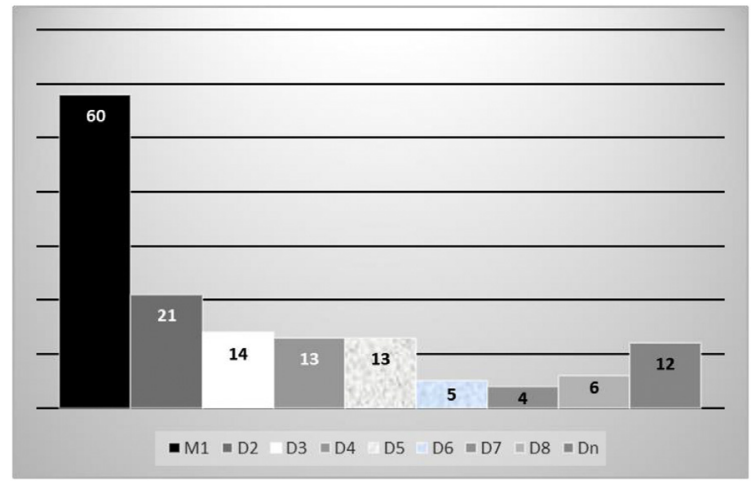

Fig. 1. Irony and humor located in a single turn (M1) and the extension of the response (D2-Dn).

As for percentages, the instances in which the LDP is fulfilled, that is to say, instances that are restricted to a single turn, account for $40.54 \%$ of the corpus, as opposed to $59.46 \%$ where there is a response in one way or another (see Fig. 2 ).

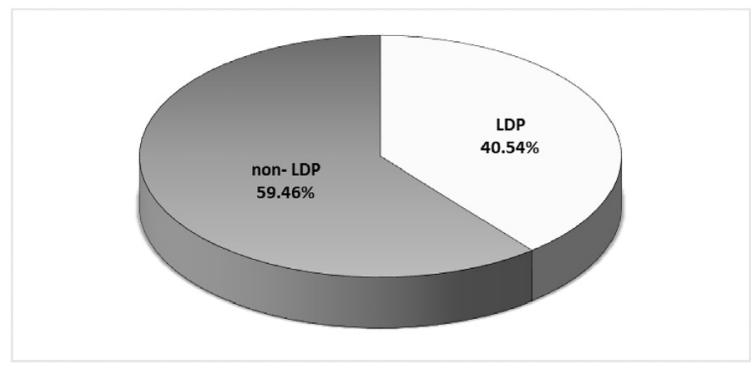

Fig. 2. Behavior of ironic-humorous sequences in colloquial conversations. 
In terms of the type of response, in 10 instances there were responses to the said (11.36\%), in 17 to the implied (19.32\%), in 12 with laughter (13.64\%) and in 49 there was a mixed response in which they mainly responded to the said or to the implied, combined mainly with laughter (55.68\%) (see Fig. 3).

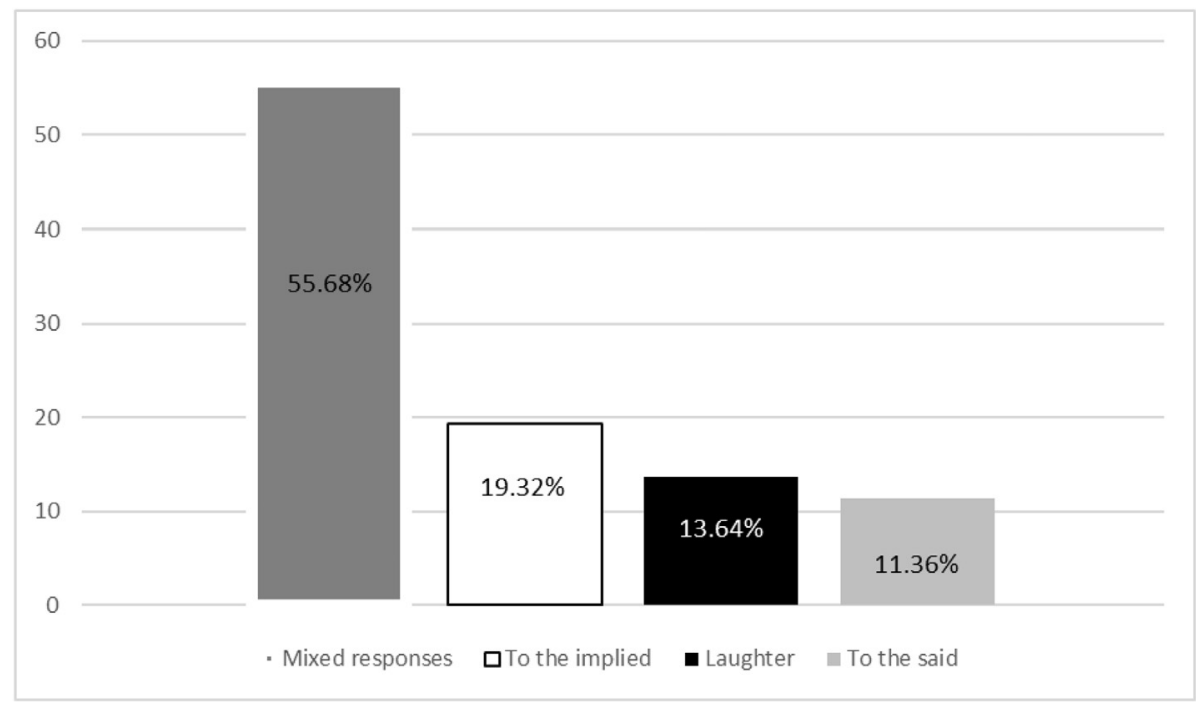

Fig. 3. Types of responses (D2-Dn): mixed response, to the implied, laughter and to the said.

As Attardo and his colleagues rightly stated (Eisterhold et al., 2006; Attardo et al., 2011, 2013), irony is frequently concentrated in a single turn, and when it is responded to, there is a subsequent turn which in most instances is with laughter. Therefore, the data supports the first point, since 40\% of the sequences respect the LDP (M1) and 14\% sustain the irony in a subsequent turn (D2), which together account for 54\% of the total. In this way, we might say that prototypical irony is that in which the conversation is interrupted with a single humorous turn or that which is added to by a subsequent turn (see Fig. 4).

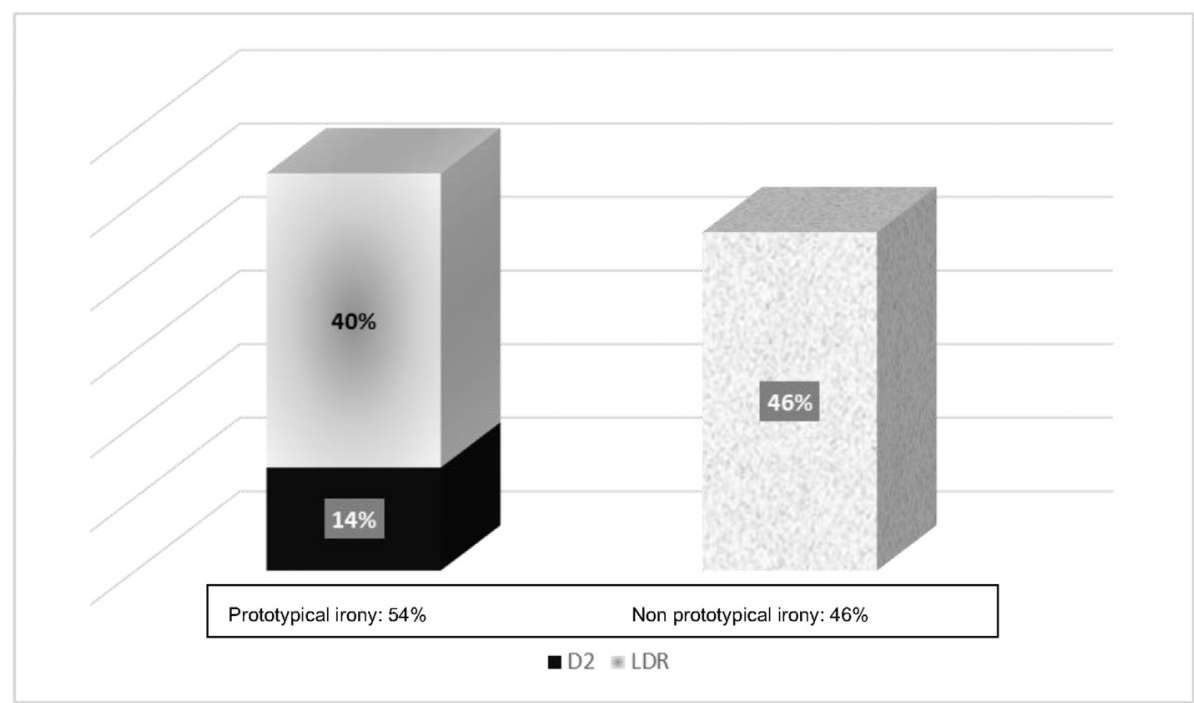

Fig. 4. Prototypical and non-prototypical irony in the Val.Es.Co. corpus.

However, as opposed to the aforesaid by Eisterhold et al. (2006: 1250), VALESCO.HUMOR did not support the point that irony is usually responded to with laughter. Laughter occurs in 35.18\% of the cases in Eisterhold et al. (2006) corpus, whereas it 
represents $13.64 \%$ of instances of our corpus, in which a mixed response accounts for $55.68 \%$ of the sequences, a response to the implied $19.32 \%$ and $11.36 \%$ to the said (as expressed in Fig. 3).

When assessing the type of response provided over the two or more turns, the entire responses have been taken into account and not just the first turn, as is the case for D2. This provides some results in which it is notable that the longer this response is extended over different turns, the more typical it is to find mixed responses, as shown in Fig. 5.

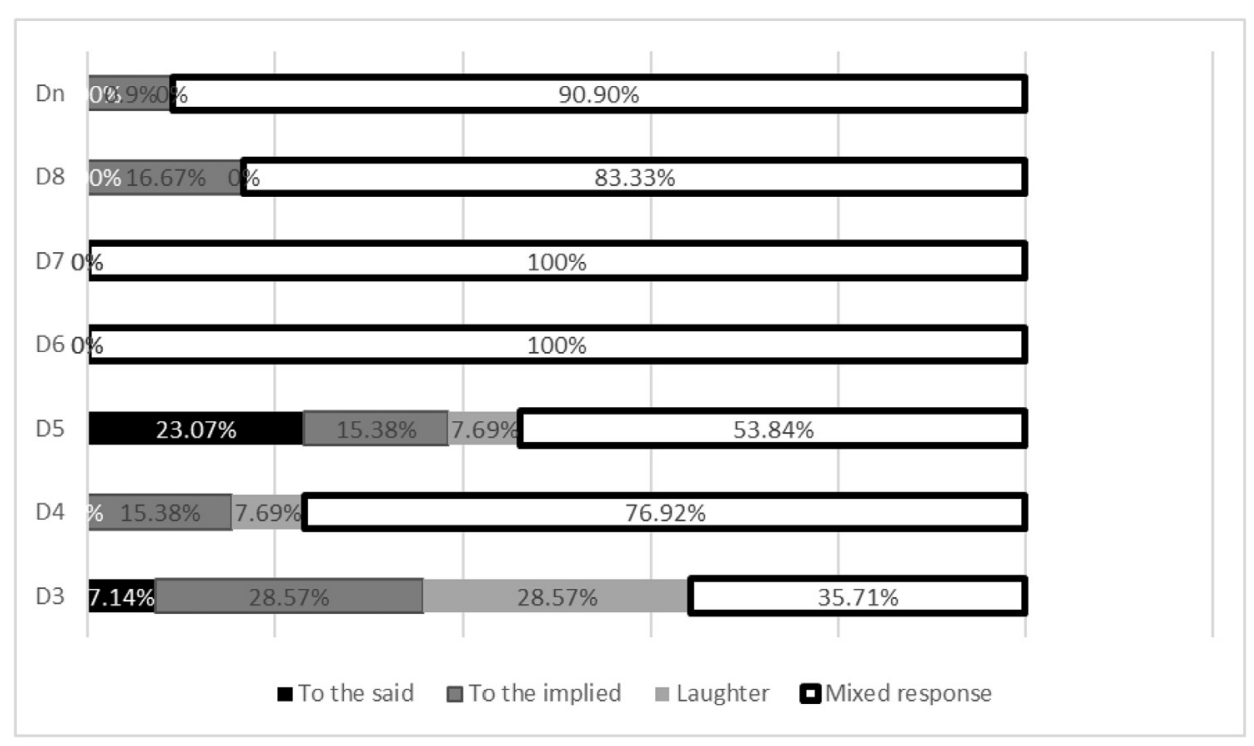

Fig. 5. Types of response (D3-Dn): to the said, to the implied, laughter and mixed response.

Among this data, it is worth noting that the responses provided over more than six turns (D6-Dn) tend to be mixed responses. It is especially noteworthy that the humorous sequences with more than eight turns (Dn) frequently combine mixed responses. Hence, the highest percentage (90.90\%) is the mixed one where laughter is mainly combined with a response to the implied, although sometimes also to the said. Just in one instance, which accounts for 9.09\% of the sample, did the response provided not include laughter and just responded to the implied.

Furthermore, the observation that the higher mixed responses were, the more turns there were, seems to corroborate the fact that sustained humor fosters an ideal framework for colloquial conversations.

\section{Conclusions}

In this paper there has been an attempt to show how irony and humor work in colloquial conversations in Peninsular Spanish. A corpus of 67 real conversations was analyzed, from which a total of 148 humorous sequences were extracted. Generally speaking, the LDP is fulfilled to a large extent (40.54\%), as irony is restricted to a single turn. However, there is a high percentage (59.46\%) where a response is given in one way or another. Prototypical irony accounts for 54\% of the total. Therefore, regardless of absolute data, VALESCO.HUMOR corroborates a broad trend to sustained humor, which goes beyond the 3 turns established by Attardo (2019) (46\% of the humorous sequences). Consequently, the data confirms that there is a balance between the LDP and the sustained humor (hypothesis 1).

On the other way, the analysis of humorous sequences has yielded results on the frequency of types of responses. The data does not support the view that irony is typically responded to with laughter, conversely to Eisterhold et al. (2006); Attardo et al. (2011); Attardo et al. (2013), since it only occurs in 13.64\% of instances. However, it shows that although responses are mostly mixed (55.68\%), there are also responses to the implied (19.32\%) and to the said (11.36\%). Finally, the data corroborates that the progressive increase in mixed responses throughout a sequence fosters sustained humor.

Furthermore, a large part of the humorous sequences of Spanish colloquial conversations show a clear trend towards the adoption of humorous mode between participants and consequently the sustained humor. In turn, and as indicated in hypothesis 2, the texts containing colloquial conversations are ones in which social equality and a previous shared experiences among the participants, a non-marked interactional framework such as the home and non-specialized topics are crucial. These are factors which, along with the primary features of conversational dynamism between the speaker and listener, lack of planning and feedback, are conducive to the humorous mode adoption and sustained humor. As stated above, the participants in the colloquial conversations use irony and humor as group and affiliation solidarity strategies. Concretely, a 
playful mode is created between the participants (Priego-Valverde, 2003: 177; Priego-Valverde et al., 2018) and the coconstruction of the sequence (Kotthoff, 2011) helps to sustain the humor (Attardo, 2019). In these sequences humor is supported (Hay, 2001) with amusing comments, with laughter and other elements (Ruiz-Gurillo, 2019).

Lines of future research may delve into these discursive strategies and determine how factors such as gender or age influence the type of response provided. In fact, a trend in female sequences for sustained humor was detected in the corpus, while in male and mixed sequences LDP seems to be prevailing. It must also be explained how recognizing humor by responding to it changes the way the conversational units (turn, turn-taking, sequence ...) are segmented. In this way, the VALESCO.HUMOR corpus will shed light on the use of humor and irony in colloquial conversations in Peninsular Spanish in the future.

\section{Funding}

This research was supported by the Spanish Ministry of Science and Innovation through the grant PID2019-104980GB-I00 "Interactional humor in Spanish. Oral, written and technological genres" (MICINN-AEI, UE); and by the grant FFI2017-90738REDT “Thematic Research Network on Studies of Discourse Analysis" (MINECO-AEI, UE). For further information, visit the website http://dfelg.ua.es/griale/.

\section{Declaration of competing interest}

The author declares no conflict of interest.

\section{Acknowledgements}

I would like to express my gratitude to the anonymous scholars who have reviewed this article for their insightful and detailed comments. I would also like to thank Doctors Salvador Pons Bordería and Esther Linares Bernabéu for their fruitful suggestions.

\section{References}

Alvarado Ortega, Mª Belén, 2013. Failed humor in conversational utterances in Spanish: a matter of impoliteness. In: Ruiz-Gurillo, Leonor, AlvaradoOrtega, María Belen (Eds.), Irony and Humor: from Pragmatics to Discourse. John Benjamins, Amsterdam, pp. $191-217$.

Alvarado Ortega, Mª Belén, 2014. Humor y género: análisis de conversaciones entre mujeres. Feminismo/s 24, 17-40.

Alvarado Ortega, $\mathrm{M}^{\mathrm{a}}$ Belén, 2016a. Variability, adaptability and negotiability in conversational humor: a question of gender. In: Ruiz-Gurillo, Leonor (Ed.), Metapragmatics of Humor: Current Research Trends, IVITRA Research in Linguistics and Literature. John Benjamins, Amsterdam, pp. $192-214$.

Alvarado Ortega, M ${ }^{\mathrm{a}}$ Belén, 2016b. Descortesía y humor fallido en conversaciones entre hombres y mujeres. Pragmática Sociocultural/Sociocultural Pragmatics 42, 243-267.

Anolli, Luigi, Giaele Infantino, Maria, Ciceri, Rita, 2001. You're a real genius!: irony as a miscommunication design. In: Anolli, Luigi, Ciceri, Rita, Riva, Giuseppe (Eds.), Say Not Say: New Perspectives on Miscommunication. IOS Press, Amsterdam, pp. $141-163$.

Attardo, Salvatore, 1997. Locutionary and perlocutionary cooperation: the perlocutionary cooperative principle. J. Pragmat. $27,753-779$.

Attardo, Salvatore, 1999. The Place of Cooperation in Cognition. European Conference of Cognitive Science ECCS’99 Siena, Italy, October. 1999.

Attardo, Salvatore, 2001. Humorous Texts: A Semantic and Pragmatic Analysis. Mouton de Gruyter, Berlin.

Attardo, Salvatore, 2019. Humor and mirth. Emotions, embodied cognition, and sustained humor. In: Mackenzie, Lachlan J., Alba-Juez, Laura (Eds.), Emotion in Discourse. John Benjamins, Amsterdam, pp. 189-211.

Attardo, Salvatore, 2020. Discourse Analysis: Humor in Conversation II, the Linguistics of Humor: an Introduction. Oxford University Press, Oxford, pp. 263-298.

Attardo, Salvatore, Raskin, Viktor, 1991. Script theory revisited: joke similarity and joke representation model. Humor 4 (3-4), $293-347$.

Attardo, Salvatore, Pickering, Lucy, Baker, A., 2011. Prosodic and multimodal markers of humor in conversation. Pragmat. Cognit. $192,224-247$.

Attardo, Salvatore, Pickering, Lucy, Lomotey, Fofo, Menjo, Shigehito, 2013. Multimodality in conversational humor. Rev. Cognit. Linguist. 11 (2), $402-416$. Bell, Nancy D., 2009. Responses to failed humor. J. Pragmat. 41 (9), 1825-1836. https://doi.org/10.1016/j.pragma.2008.10.010.

Briz, Antonio Coord, Grupo Val.Es.Co, 1995. La conversación coloquial, Materiales para su estudio. Universitat, Anejo XVI de Cuadernos de Filología, València. Briz, Antonio, Grupo Val.Es.Co, 2002. Corpus de conversaciones coloquiales. Arco/Libros, Madrid.

Burgers, Christian, van Mulken, Margot, 2017. Humor markers. In: Attardo, Salvatore (Ed.), The Routledge Handbook of Language and Humour. Routledge. Taylor and Francis, pp. 385-399.

Coates, J., 2007. Talk in a play frame: more on laughter and intimacy. J. Pragmat. 391, 29-49.

Coates, Jennifer, 2014. Gender and humor in everyday conversation. In: Chiaro, Delia, Baccolini, Raffaela (Eds.), Gender and Humor. Interdisciplinary and International Perspectives. Routledge, London, pp. 147-164.

Davies, Catherine E., 2003. How English-learners joke with native speakers: an interactional sociolinguistic perspective on humor as collaborative discourse across cultures. J. Pragmat. 35, 1361-1385.

Davies, Catherine E., 2006. Gendered sense of humor as expressed through aesthetic typifications. J. Pragmat. 38, $96-113$.

Davies, Catherine E., 2017. Sociolinguistic approaches to humor. In: Attardo, Salvatore (Ed.), The Routledge Handbook of Language and Humour. Taylor and Francis, Routledge, pp. 472-488.

Dynel, Marta, Sinkeviciute, Valeria, 2017. Conversational humour: Spotlight on languages and cultures. Spec. Issue Lang. Commun. 55.

Eisterhold, Jodi, Attardo, Salvatore, Boxer, Diana, 2006. Reactions to irony in discourse: evidence for the least disruption principle. J. Pragmat. 38, 1239-1256.

Gibbs, Raymond W., Colston, Herbert L., 2001. The risks and rewards of ironic communication”. In: Anolli, Luigi, Ciceri, Rita, Riva, Giuseppe (Eds.), Say Not Say: New Perspectives on Miscommunication. IOS Press, Amsterdam, pp. 187-200.

Giora, Rachel, Gur, Inbal, 2003. Irony in conversation: salience, role, and context effects. In: Nerlich, B., Todd, Z., Herman, V., Clarke, D. (Eds.), Polysemy. Flexible Patterns of Meaning in Mind and Language. Mouton de Gruyter, Berlin/New York, pp. 297-315.

Glenn, Phillip, Holt, Elizabeth, 2017. Conversation analysis of humor. In: Attardo, Salvatore (Ed.), The Routledge Handbook of Language and Humour. Taylor and Francis, Routledge, pp. 295-308.

Goddard, Cliff, 2020. De-Anglicising humour studies. Eur. J. Hum. Res. 8 (4), 48-58. 
Goffman, Erving, 1981. Forms of Talk. University of Pennsylvania Press.

Gumperz, J.J., Hymes, Dell H. (Eds.), 1986. Directions in Sociolinguistics: the Ethnography of Communication. Basil Blackwell, Oxford.

Haugh, Michael, Weinglass, Lara, 2018. Divided by a common language? Jocular quips and (non-)affiliative responses in initial interactions among American and Australian speakers of English. Intercult. Pragmat. 15 (4), 533-562. https://doi.org/10.1515/ip-2018-0019.

Hay, Jennifer, 2000. Functions of humor in the conversations of men and women. J. Pragmat. 32, 709-742.

Hay, Jennifer, 2001. The pragmatics of humor support. Humor 14 (1), 55-82.

Holmes, Janet, Marra, Meredith, Burns, Louise, 2001. Women's humour in the workplace: a quantitative analysis. Aust. J. Commun. 28 (1), $83-108$.

Kotthoff, Helga, 2000. Gender and joking. On the complexities of women's image politics in humorous narratives. J. Pragmat. 32 (1), 55-80.

Kotthoff, Helga, 2003. Responding to irony in different contexts: on cognition in conversation. J. Pragmat. 32, 1387-1411.

Kotthoff, Helga, 2006a. Gender and humor: the state of the art. J. Pragmat. 38, 4-25.

Kotthoff, Helga, 2006b. Pragmatics of performance and the analysis of conversational humour. Humor 193, 271-304.

Kotthoff, Helga, 2011. Co-creating fantastic pretense scenarios. In: Paper Delivered at 12th International Pragmatics Conference IPrA Association. Manchester, 3-8 July 2011.

Lampert, Martin, Ervin-Tripp, Susan M., 1998. Exploring paradigms: the study of gender and sense of humor near the end of the 20th century". In: Ruch, Willibad (Ed.), The Sense of Humor: Explorations of a Personality Characteristic. Mouton de Gruyter, Berlin, pp. 231-270.

Lampert, Martin, Ervin-Tripp, Susan M., 2006. Risky laughter: teasing and self-directed joking among male and female friends. J. Pragmat. 38, 51-72.

Mullan, Kerry, Béal, Christine, 2018. Conversational humor: forms, functions and practices across cultures. Special issue of Intercult. Pragmat. 15 (4).

Mullan, Kerry, Vincent-Durroux, Laurence, David, Caroline, 2020. Humour across cultures - a contrastive approach. Special issue of Eur. J. Hum. Res. 8 (4).

Norrick, Neal R., 2003. Issues in conversational joking. J. Pragmat. 35, 1333-1359.

Norrick, Neal R., Chiaro, Delia (Eds.), 2009. Humor in Interaction. John Benjamins, Amsterdam.

Norrick, Neal.R., Spitz, Alice, 2008. Humor as a resource for mitigating conflict in interaction. J. Pragmat. 40 (10), 1661-1686.

Norrick, Neal.R., Spitz, Alice, 2010. The interplay of humor and conflict in conversation and scripted humorous performance". Humor 23 (1), 83-111.

Partington, Alan, 2006. The Linguistics of Laughter: A Corpus-Assisted Study of Laughter-Talk. Routledge, London.

Priego-Valverde, Béatrice, 2003. L'humour dans la conversation familière: Description et analyse linguistiques. L'Harmattan, Paris.

Priego-Valverde, Béatrice, 2006. How funny it is when everybody gets going! A case of co-construction of humor in conversation. Círculo Lingüística Apl Comunicación (CLAC) 27, 72-100.

Priego-Valverde, Béatrice, Bigi, Brigitte, Attardo, Salvatore, Pickering, Lucy, Gironzetti, Elisa, 2018. Is smiling during humor so obvious? A cross-cultural comparison of smiling behavior in humorous sequences in American English and French interactions. Intercult. Pragmat. 15 (4), 563-591.

Raskin, Victor, 1985. Semantic Mechanisms of Humor. Reidel, Dordrecht.

Raskin, Viktor, 2007. The sense of humor and the truth. In: Ruch, Willibald (Ed.), The Sense of Humor: Explorations of a Personality Characteristic. Walter de Gruyter, Berlin, pp. 95-108.

Ruiz-Gurillo, Leonor, 2009. ¿Cómo se gestiona la ironía en la conversación? RILCE 23 (2), 363-377.

Ruiz-Gurillo, Leonor, 2012. La lingüística del humor en español. Arco/Libros, Madrid.

Ruiz-Gurillo, Leonor, 2014. Infiriendo el humor. Un modelo de análisis para el español. Círculo Lingüística Apl. Comunicación (CLAC) 59, $148-162$.

Ruiz-Gurillo, Leonor, 2016. Metapragmatics of humor: variability, negotiability and adaptability in humorous monologues. In: Ruiz-Gurillo, Leonor (Ed.), Metapragmatics of Humor: Current Research Trends. John Benjamins, Amsterdam, pp. 81-104. https://doi.org/10.1075/ivitra.14.05rui.

Ruiz-Gurillo, Leonor, 2019. Humor de género. Del texto a la identidad en español. Iberoamericana Vervuert, Madrid.

Ruiz-Gurillo, Leonor, Padilla-García, Xose (Eds.), 2009. Dime cómo ironizas y te diré quién eres. Una aproximación pragmática a la ironía. Peter Lang, Frankfurt.

Sacks, Harvey, Schegloff, Emanuel A., Jefferson, Gail, 1974. A simplest systematics for the organisation of turn taking for conversation. Language 50, 696-735.

Schegloff, Emanuel A., 2007. Sequence Organization in Interaction: A Primer in Conversation Analysis. CUP, Cambridge.

Schnurr, Stephanie, Plester, Barbara, 2017. Functionalist discourse analysis of humor. In: Attardo, Salvatore (Ed.), The Routledge Handbook of Language and Humor 309-321. Routledge Abingdon.

Shilikhina, Ksenia, 2017. Metapragmatic Markers of the Bona Fide and Non-bona Fide Modes of Communication. In: Chlopicki, Wladyslaw, Brzozowska, Dorota (Eds.), Humorous Discourse. Mouton de Gruyter, Amsterdam, pp. 107-130.

Sinkeviciute, Valeria, 2019. Conversational Humour and (Im) Politeness: A Pragmatic Analysis of Social Interaction. John Benjamins, Amsterdam.

Sinkeviciute, Valeria, Dynel, Marta, 2019. Approaching conversational humour culturally: a survey of the emerging area of investigation. Lang. Commun. 55, $1-9$.

Tsakona, V., 2011. Irony beyond criticism: evidence from Greek parliamentary discourse. Pragmat. Soc. 21, 57-86.

Wilson, Deirdre, 2000. Metarepresentation in linguistic communication. In: Sperber, Dan (Ed.), Metarepresentations. A Multidisciplinary Perspective. University Press, Oxford, pp. 411-448.

Leonor Ruiz-Gurillo is a Full Professor of Spanish Linguistics at the University of Alicante (Spain). She is the leader of the GRIALE research group (http://dfelg. ua.es/griale/) and a co-founder of the Val.Es.Co. research group. Her research interests include humor, irony, phraseology, spoken Spanish and pragmatics. Currently, her core work has focused on humor, gender and identity. She is co-editor of Irony and Humor: From Pragmatics to Discourse (Amsterdam, John Benjamins, 2013) and editor of Metapragmatics of Humor: Current Research Trends (Amsterdam: John Benjamins, 2016). 